\title{
PROTOTYPE ALAT PEMBATAS DAN PEMUTUS ARUS LISTRIK PASCABAYAR PADA RUMAH TANGGA BERBASIS SMARTPHONE
}

\author{
RAHMA FARAH NINGRUM, HERMAN BEDI AGTRIADI, \\ \& NOVITA ROSE MARISI PARDEDE \\ Jurusan Teknik Informatika STT-PLN Jakarta \\ Jl.Lingkar Luar, Duri, Kosambi, Cengkareng, Jakarta Barat 11750 \\ Email: rahmafarah@sttpln.ac.id
}

\begin{abstract}
Electricity consumption in the household sector is $37.5 \%$ of total energy consumption. In 2017 Basic Electricity Fare (BEF) has increased 4 times. To suppress the high price that must be paid every month from the use of electrical energy and to anticipate the occurrence of energy crisis required a system that can limit the use of electrical energy. Therefore, a system that can control and limit the use of electrical energy. The system uses the arduino as the control center of the model circuit component, then connected to the current-breaker application on the user's smartphone. So with this system people can control and limit the usage of electric current with ease, therefore the savings on electrical energy can be done and also is one way to anticipate the occurrence of energy crisis in the future.
\end{abstract}

Keywords: Electrical Energy, Basic Electricity Fare (BEF), Electric Current Limitation, Application, Arduino, Smartphone.

\begin{abstract}
ABSTRAK
Pemakaian energi listrik pada sektor rumah tangga mencapai 37,5\% dari total pemakaian energi secara keseluruhan. Tahun 2017 Tarif Dasar Listrik (TDL) mengalami kenaikan sebanyak 3 kali. Untuk menekan tingginya harga yang harus dibayarkan setiap bulannya dari pemakaian energi listrik dan untuk mengantisipasi terjadinya krisis energi dibutuhkan sebuah sistem yang dapat membatasi pemakaian energi listrik tersebut. Oleh karena itu dibuatlah sistem yang dapat mengontrol dan membatasi pemakaian energi listrik. Sistem ini menggunakan arduino sebagai pusat kontrol dari komponen rangkaian model, kemudian dihubungkan dengan aplikasi pemutus arus pada smartphone pengguna. Sehingga dengan sistem ini masyarakat dapat mengontrol dan membatasi pemakaian arus listrik dengan mudah, maka dari itu penghematan akan energi listrik dapat dilakukan dan juga merupakan salah satu cara untuk mengantisipasi terjadinya krisis energi dimasa yang akan datang.
\end{abstract}

Kata kunci: Energi listrik, Tarif Dasar Listrik (TDL), pembatasan arus listrik, Aplikasi, Arduino, Smartphone.

\section{PENDAHULUAN}

Kebutuhan listrik nasional rata-rata tumbuh sekitar $8-9 \%$ per tahun. Angka ini berarti bahwa setiap tahun harus ada tambahan sekitar 5.700 MW kapasitas pembangkit baru. Hal ini menjadi tantangan besar bagi Pemerintah dalam penyediaan listrik karena dibutuhkan dana yang begitu besar dalam investasi infra- struktur ketenagalistrikan, mulai dari pembangunan pembangkit-pembangkit baru, jaringan transmisi, ketersediaan SDM (sumber daya alam) yang menjadi komponen utama penghasil energi listrik, hingga jaringan distribusi agar listrik dapat disalurkan hingga ke konsumen. Konsumsi energi listrik cukup banyak terdapat pada sektor rumah tangga. Pada tahun 
2011, konsumsi energi pada sektor rumah tangga di Indonesia dari total konsumsi energi final adalah kedua terbesar setelah sektor industri, yaitu mencapai 319.280.000 SBM atau $37,5 \%$ dari total konsumsi energi final, maka dari itu perlunya sebuah sistem yang dapat melakukan penghematan dan pembatasan serta Pengendalian akan penggunaan energi listrik sebagai langkah awal yang dapat dilakukan untuk mengantisipasi terjadinya krisis energi dimasa yang akan datang dan untuk menekan tingginya harga yang harus dibayarkan perbulannya dari setiap pemakaian energi listrik. Untuk bisa mengatur penggunaan listrik sesuai dengan kebutuhan dalam pemakaian sektor rumah tangga, dibutuhkan sebuah sistem yang mampu membatasi pemakaian arus listrik sesuai dengan batasan yang diinputkan dalam sistem, hal ini sangat memudahkan bagi masyarakat yang ingin menghemat penggunaan listrik dan pengontrolan pemakaian arus listrik.

\section{a. Sensor Arus}

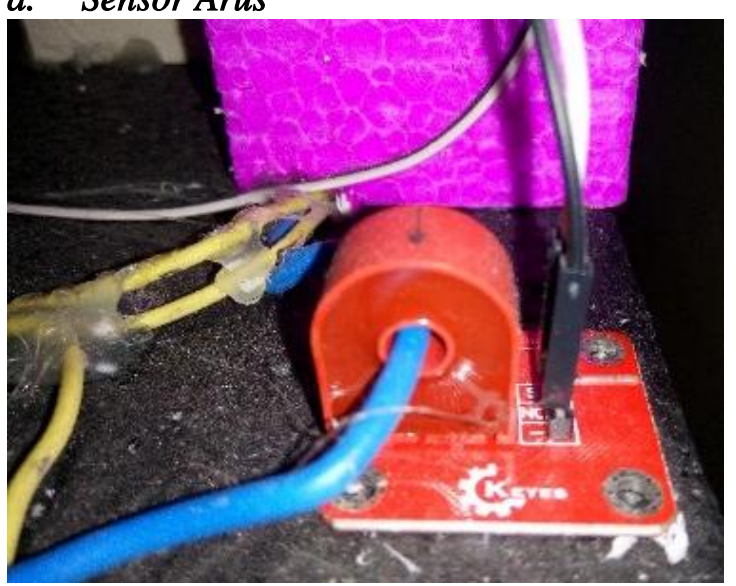

Gambar 1 Sensor Arus TA12-200.

Pada gambar 1 merupakan sensor arus tipe TA12-200 yang digunakan pada rangkaian alat pembatas dan pemutus arus listrik pada rumah tangga. Sensor arus digunakan untuk mendeteksi jumlah arus yang mengalir pada rangkaian maket rumah sederhana, sensor arus memiliki 3 pin namun yang terpakai pada pembuatan ini hanya 2 pin yaitu pada sensor arus $\mathrm{A}$ pin $\mathrm{S}$ yang tersambung pin $\mathrm{A} 0$ pada arduino pada dan pin (-) yang tersambung pin Gnd pada arduino sedangkan pada sensor arus $\mathrm{B}$ pin $\mathrm{S}$ yang tersambung pin A2 pada arduino pada dan pin (-) yang tersambung pin Gnd pada arduino.

\section{b. Sensor Tegangan}

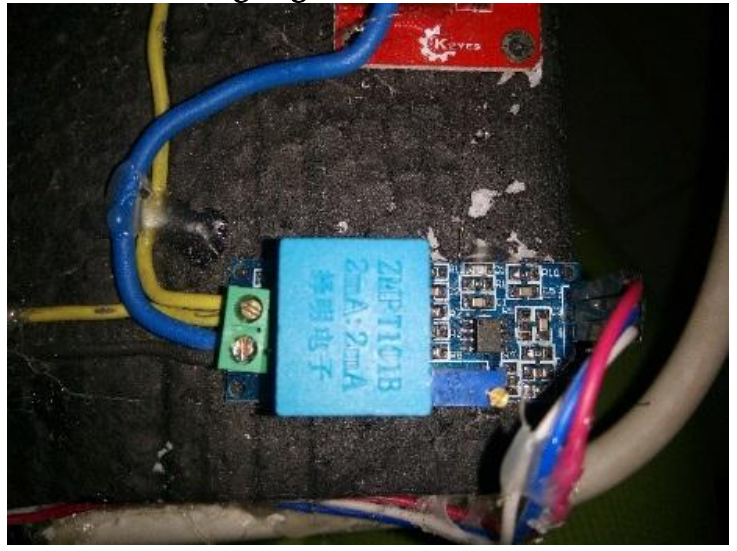

Gambar 1 Sensor Tegangan.

Pada gambar 2 merupakan sensor tegangan (Voltage) tipe ZMPT101B Ultra Micro Voltage Transformer yang digunakan pada rangkaian alat pembatas dan pemutus arus listrik pada rumah tangga. Berfungsi mendeteksi tegangan pada rangkaian maket rumah sederhana. Sensor tegangan memiliki 4 kaki dan digunakan hanya 3 pin yang terhubung pada arduino yaitu pin (+) yang tersambung pada pin $5 \mathrm{~V}$ arduino, pin Gnd yang tersambung pada pin Gnd Arduino, Pin terhubung pada pin A1 arduino

\section{c. Smartphone}

Menurut Williams \& Sawyer (2011), smartphone adalah telepon selular dengan mikroprosesor, memori, layar dan modem bawaan. Smartphone merupakan ponsel multimedia yang menggabungkan fungsionalitas PC dan handset sehingga menghasilkan gadget yang mewah, di mana terdapat pesan teks, kamera, pemutar musik, video, game, akses email, tv digital, search engine, pengelola informasi pribadi, fitur GPS, jasa telepon internet dan bahkan terdapat telepon yang juga berfungsi sebagai kartu kredit. Smartphone atau bisa disebut dengan telepon pintar/cerdas sudah menjadi sebuah kebutuhan bagi sekian orang di dunia ini sebagai penunjang aktivitas kerja maupun sekedar lifestyle atau gaya hidup. Telepon cerdas (smartphone) adalah telepon genggam yang mempunyai kemampuan tingkat tinggi, kadang-kadang dengan fungsi yang menyerupai komputer.

\section{METODE PENELITIAN \\ a. Diagram Alir Penelitian}

Gambar 3 dibawah ini menunjukkan diagram alir langkah-langkah yang dilaksanakan dalam penelitian ini. Adapun penjelasannya adalah sebagai berikut: 


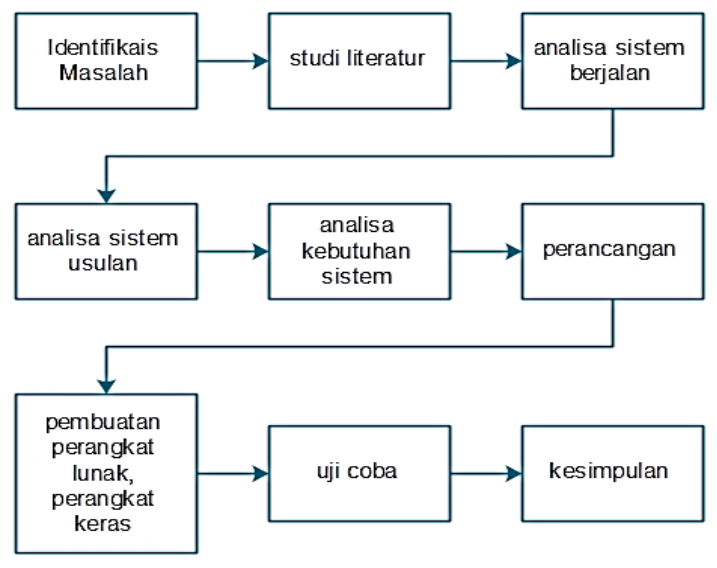

Gambar 3 Blok Diagram Alir Penelitian

\section{1) Identifikasi Masalah}

Pada tahap ini penulis merumuskan permasalahan yang ditemukan:

a) Sistem pemutus arus listrik saat ini atau yang lebih dikenal dengan Mini Circuit Breakers (MCB) akan trip(turun) pada saat beban arus yang digunakan sudah melewati kapasitas arus yang telah disediakan. Sistem yang ada saat ini belum bisa memberikan pemberitahuan atau peringatan tentang adanya beban arus berlebih.

b) Pembatasan penggunaan arus listrik dibutukan agar dapar mengontrol penggunaan arus listik rumah tangga

c) Akses on dan off perangkat elektronik dibutuhkan agar dapar memilih perangkat elektronik mana yang akan di mati/hidupkan jika peringatan arus lebih menyala.

\section{2) Study Literatur}

Studi literatur pustaka yang berkaitan dengan masalah pembuatan rancang bangun alat pembatas dan pemutus arus, dimulai dari sensor arus, sensor tegangan, relay, pemrograman Arduino, App Inventor, MySQL, beserta komponen pendukung lainnya. Penulis juga melakukan pembedahan buku dan mempelajari unsur dari objek yang diteliti serta mempelajari buku petunjuk dari masing-masing komponen dan mencari berita dari internet mengenai seputar topik permasalahan yang diambil.

\section{3) Analisa Sistem Berjalan}

Penulis melakukan analisa terhadap sistem yang sudah ada dan sedang berjalan pada saat ini, bagaimana cara kerja sistem tersebut.

\section{4) Analisa Sistem Usulan}

Setelah melakukan analisa pada sistem yang sedang berjalan maka penulis menyusun sistem usulan yang akan di bangun pada penelitian ini.

\section{5) Analisa Kebutuhan Sistem}

Analisa kebutuhan yaitu, menganalisa tentang perangkat keras dan perangkat lunak apa saja yang dibutuhkan pada sistem usulan penelitian yang dilakukan penulis.

\section{6) Perancangan}

Setelah melakukan tahap analisa, tahap selanjutnya yaitu perancanga. Pada tahap ini penulis membuat perancangan untuk perangkat keras (hardware) yang akan dirangkai, perancangan perangkat lunak (software) dan interface sebagai media penghubung kepada pengguna (user).

\section{7) Pembuatan Perangkat Lunak dan Perangkat Keras}

Dalam pembuatan perangkat lunak (software) hal yang dilakukan adalah pengkodean yang menghubungkan sensor agar dapat terhubung dengan arduino untuk dapat membaca data nilai arus yang mengalir pada rangkaian dan menyimpan data yang dikirmkan tersebut kedalam database, lalu dapat ditampilakan pada aplikasi, serta membuat aplikasi dapat memati hidupkan perangkat elektronik dan pusat arus yang sudah didaftarkan. Sedangkan untuk pembuatan interface hal yang dilakukan yaitu pengkodean untuk membuat sebuah aplikasi yang menarik digunakan dan mudah untuk dipahami untuk pengguna (user). Dari hasil rancangan alat kemudian dibuatlah rancang bangun alat pembatas dan pemutus arus listrik yang berguna sebagai pengontrol pemakaian arus listrik pada rumah tangga. Perangkat keras terdiri dari sensor arus, sensor tegangan, relay, buzzer, papan breadboard yang dihubungkan pada arduino uno.

\section{8) Uji Coba}

Setelah aplikasi sistem pembatas dan pemutus ini selesai dirancang, kemudian dilakukan uji coba sistem yang telah dibuat, apakah telah sesuai dengan yang dibutuhkan atau tidak. Apabila belum sesuai, dilakukan kembali perancangan sistem untuk memperbaiki kesalahan sehingga sistem yang dibuat sesuai dengan yang diinginkan. 


\section{b. Perancangan perangkat keras}

Pada gambar 4 dibawah ini adalah gambar rangkaian perangkat keras alat pembatas dan pemutus arus listrik pada rumah tangga, dibagi menjadi tiga komponen yaitu input, proses dan output.

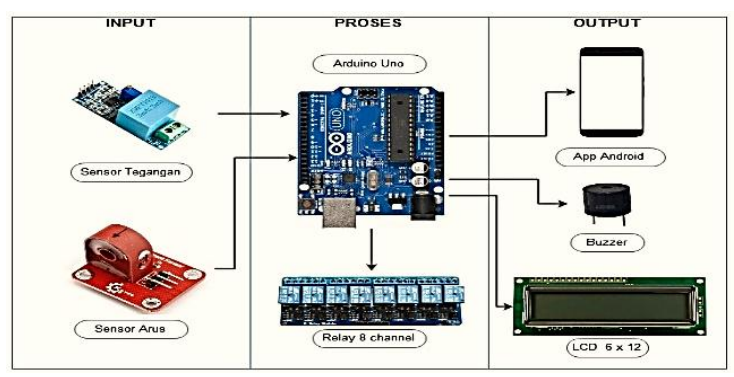

Gambar 2 Perancangan Perangkat Keras.

\section{c. Perancangan Perangkat Lunak}

Pada gambar 5 dibawah ini mengambarkan perancangan perangkat lunak, dimana menjelaskan tentang proses bagaimana jumlah arus listrik terpakai yang terdeteksi pada sensor arus dapat ditampilkan dan dilihat oleh pengguna (user). Proses dimulai dari Rangkaian rancang bangun alat pembatas dan pemutus arus yang yang telah terhubung dengan arduino sebagai media kontrol dari alat-alat yang terhubung satu sama lainnya. Setelah data jumlah arus yang terpakai terdeteksi arduino akan mengirimkan data pada laptop dimana webserver berada melalui serial usb dan kemudiaan disimpan dalam database ретиtus_arus.sql. Data yang telah tersimpan kemudiakan akan dipanggil dan ditampilkan pada aplikasi pemutus arus pada smartphone pengguna (user) dan pada layar LCD pada rangkaian model rumah sederhana.

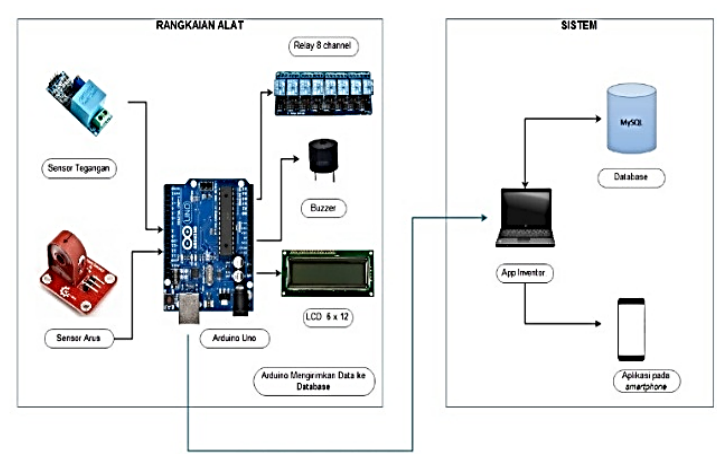

Gambar 5 Perancangan Perangkat Lunak.

\section{d. Prinsip Kerja Perangkat Keras dan Perangkat Lunak}

Sensor arus pada rangkaian model akan mendeteksi jumlah pemakaian arus listrik terpakai pada rangkaian model begitu juga dengan nilai tegangan yang mengalir. Data nilai arus dan tegangan akan di kirim terbaca pada serial arduino, kemudian dikirimkan kedalam database pada laptop/pc dengan menggunakan serial usb. Prinsip kerja pada rancang bangun alat pembatas dan pemutus arus listrik pascabayar pada rumah tangga berbasis smartphone ini dapat di lihat pada gambar 6 dibawah ini.

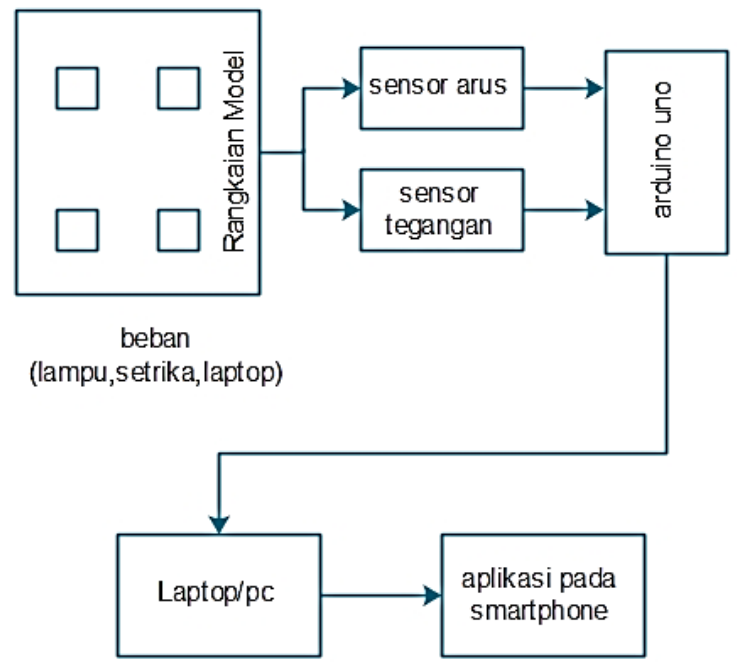

Gambar 3 Rancangan Rangkaian Alat.

\section{e. Perancangan Alur Kerja Program}

1) Flowchart Logika Pembatas Arus

Pada gambar 7 dibawah ini menjelaskan bagaimana pemutusan arus dapat terjadi, Masukkan nilai batas arus_maksimum atau nilai batas pemakaian arus listrik diinputkan pada kode program arduino, misalkan arus_maksimum $=5$ berarti jika nilai pemakaian arus listrik >5 maka pemutusan arus listrik akan terjadi. Nilai pemakaian arus listrik didapat dari beban (lampu/perangkat elektronik) arus listrik yang dihubungkan pada stop kontak pada rangkaian model.

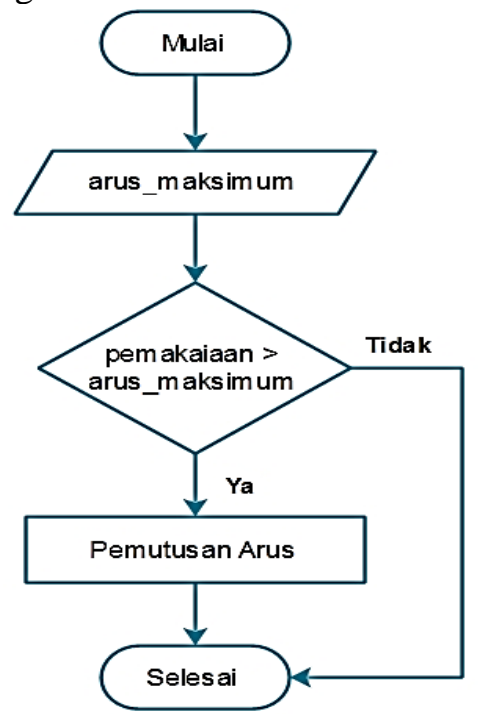

Gambar 7 Flowchart Pemutus Arus. 
2) Flowchart Logika Pemberitahuan (Notifikasi)

Flowchart gambar. 8 dibawah ini merupakan alur kerja bagaimana sebuah pemberitahuan dapat dikirimkan pada aplikasi pada smartphone pengguna, dna buzzer pada rangkaian model berbunyi.

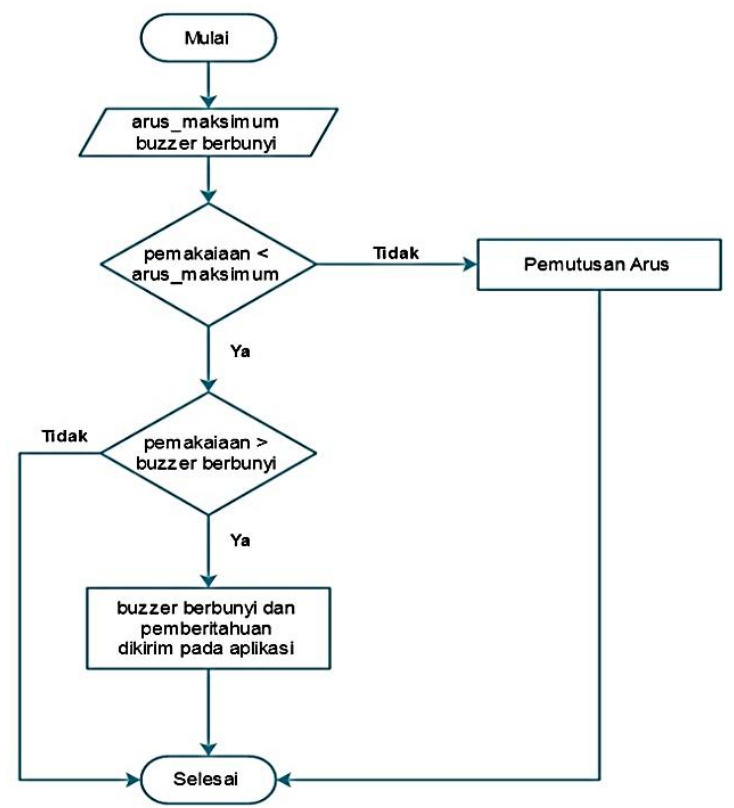

Gambar 8 Flowchart Pemberitahuan

\section{3) Flowchart Logika Pemutusan Arus Oto- matis}

Pada flowchart gambar 9 menjelaskan bagaimana proses pemutus arus otomatis akan terjadi pada sistem yang akan dibangun. Hal yang pertama yaitu masukkan nilai batas pemakaian arus maksimum pada inisialisasi arus_maksimum didalam kode program arduino. Dimisalkan dengan angka 5, arus_maksimum $=5$. Setelah itu masukkan nilai batas pemakaian arus untuk buzzer berbunyi pada inisialisasi bunyi buzzer didalam kode program arduino. Dimisalkan dengan angka, buzzer_berbunyi > 3. Jika kondisi nilai pemakaian arus listrik kecil dari nilai batas yang telah diinputkan (pemakaian < arus_maksimum), maka tahap selanjutnya yaitu periksa kondisi pemakaian arus apakah lebih besar dari nilai batas arus pada buzzer berbunyi (pemakaian > buzzer berbunyi), jika iya buzzer akan berbunyi sebagai warning alarm, jika tidak kondisi pemakaian arus listrik dianggap dalam keadaan normal. Jika pema-kaian arus besar dari nilai arus_maksimum (pemakaian > arus_maksimum) maka pemutusan arus otomatis dari sistem akan dilakukan. Setelah buzzer berbunyi dan pemberitahuan ditampil- kan pada aplikasi, sistem akan menunggu pengurangan pemakaian arus listrik dari pengguna baik melalui aplikasi pemutus arus maupun secara manual. Buzzer akan terus berbunyi sebagai bunyi peringatan sampai nilai pemakaian arus listrik kembali pada kondisi normal. Jika pemakaian arus lebih besar dari nilai batas arus_maksimum, maka pemutusan otomatis dari sistem akan dilakukan. Nilai pemakaian arus listrik didapat dari beban (lampu/perangkat elektronik) arus listrik yang dihubungkan pada stop kontak pada rangkaian model.

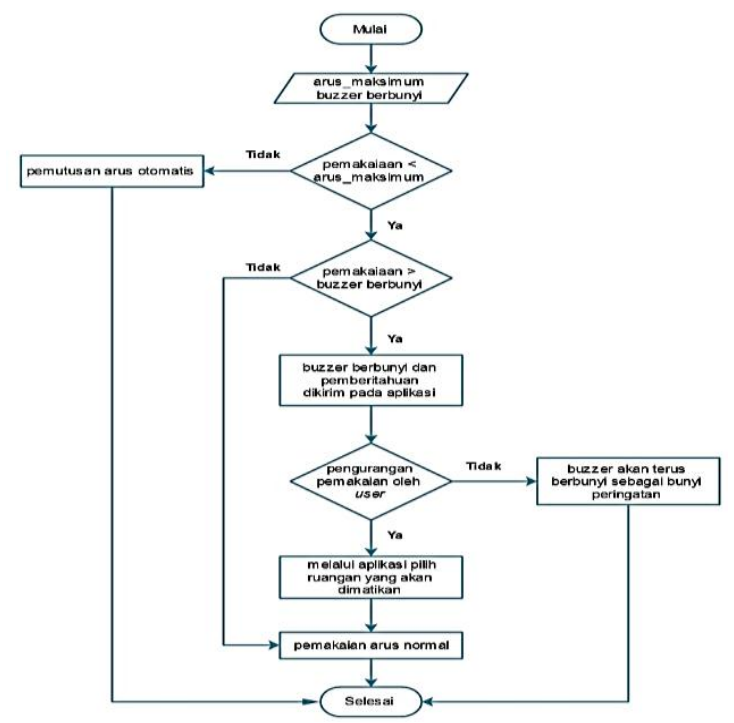

Gambar 9 Flowchart Pemutusan Arus Otomatis.

3. HASIL DAN PEMBAHASAN

a. Tampilan Rangkaian Alat Keseluruhan

Pada gambar 10 merupakan hasil rangkaian alat keseluruhan dan maket rumah sederhana, maket rumah rumah sederhana tersebut dibagi menjadi 5 ruang yaitu; teras rumah, kamar tidur, ruang tamu, dapur, dan kamar mandi. Rangkaian rumah sederhana ini dibuat dengan menggunakan streroform, terdapat 4 buah stop kontak yang akan digunakan sebagai simulasi pemasangan perangkat elektronik yang arus listrik terpakainya akan dibaca oleh sensor arus.

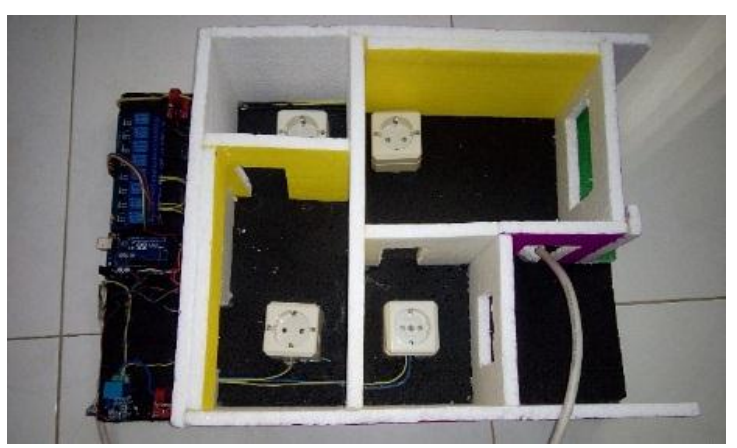

Gambar 10 Rangkaian Model Rumah Sederhana. 


\section{b. Hasil Perancangan Aplikasi \\ 1) Halaman Koneksi}

Gambar 11 dibawah ini adalah proses menginputkan ip jaringan dimana webserver berada. Aplikasi pada smartphone diharuskan masuk dalam satu jaringan yang sama dengan jaringan dimana webserver berada. Dalam hal ini penulis menggunakan modem yang dikoneksikan pada laptop dimana web server berada, selanjutnya IP pada laptop tersebut yang akan di inputkan pada halaman dibawah ini.

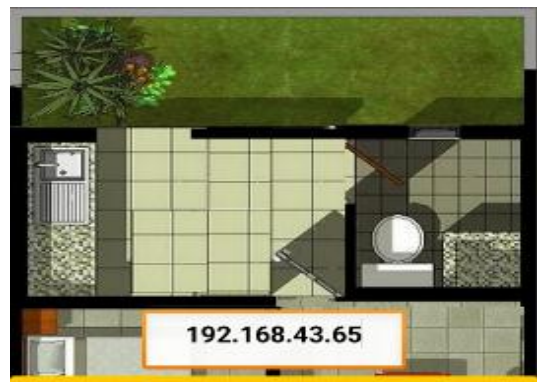

START UP SYSTEM

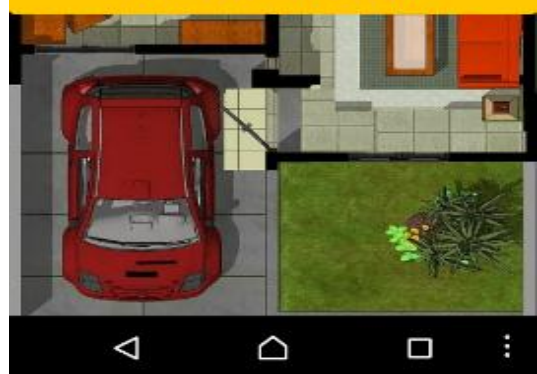

Gambar 11 Halaman Koneksi.

\section{2) Halaman Home}

Pada gambar 12 dibawah ini adalah halaman utama dari aplikasi pemutus arus terdapat 6 tombol pilihan yaitu; arus kanan, kamar tidur, dapur, arus kiri, ruang tamu, dan kamar mandi. Jika salah satu tombol di tekan, maka halaman dari tombol yang di tekan akan muncul. Contoh; jika kita menekan tombol arus kanan maka kita akan masuk pada halaman arus kanan. Pada setiap halaman dari tombol-tombol diatas terdapat tombol hidup/on dan mati/off.
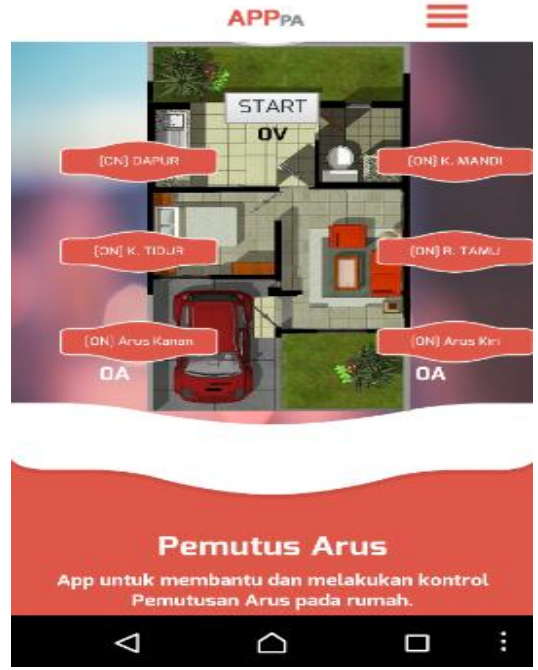

Gambar 12 Halaman Home.

\section{3) Tampilan Halaman Arus Kanan}

Pada gambar 13, hasil halaman arus kanan dari aplikasi pemutus arus diatas terdapat tombol on dan off yang berfungsi untuk memberi perintah pada sistem pemutus arus, dimana jika tombol on di tekan maka, arus listrik yang berpusat pada sensor bagian kanan rumah akan menyala dan jika tombol off ditekan maka, arus listrik yang berpusat pada bagian kanan rumah akan mati. Terdapat dua ruangan yaitu kamar tidur dan dapur yang berpusat pada sensor arus bagian arus kanan.

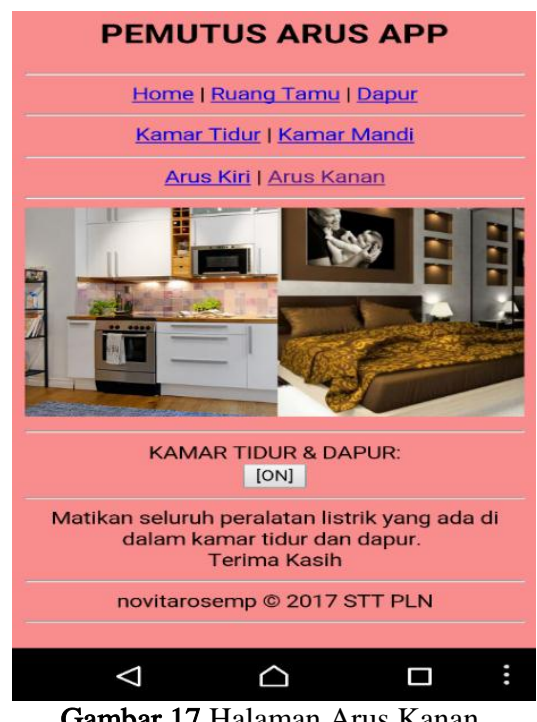

4) Tampilan Halaman Pemberitahuan

Pada gambar 14 merupakan pemberitahuan akan adanya pemakaian arus listrik berlebih yang terdeteksi pada kamar tidur dan dapur yang berpusat pada sensor arus bagian kanan. Tampilan pemberitahuan ini dikirimkan bersamaan dengan bunyi buzzer pada maket rumah sederhana. 


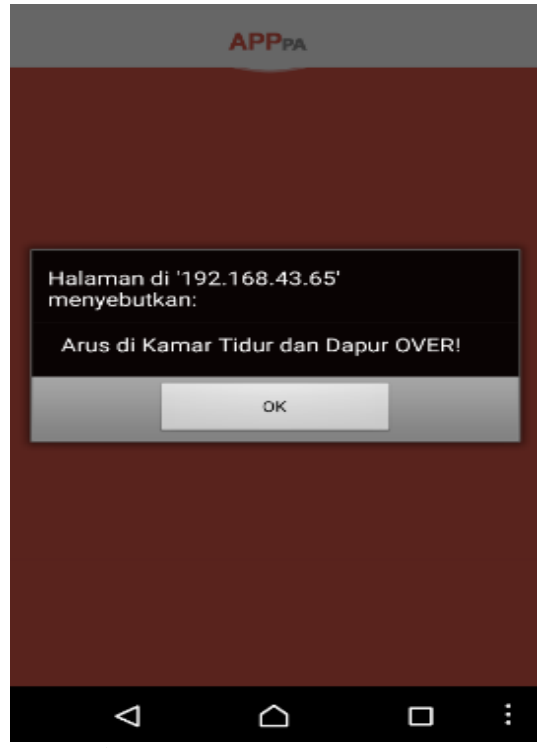

Gambar 14 Halaman Pemberitahuan.

\section{c. Cara Kerja Sensor Arus}

1) Proses Pengiriman Data

Pada rangkaian model sensor arus berfungsi untuk membaca nilai jumlah arus terpakai pada rangkaian model. Pemakaian arus pada rangkaian model dibagi menjadi dua bagian yaitu, arus_kiri dan arus_kanan, jumlah nilai pemakaian arus didapartkan dari beban (lampu/perangkat elektronik) arus listrik yang dihubungkan pada stop kontak pada rangkaian model.

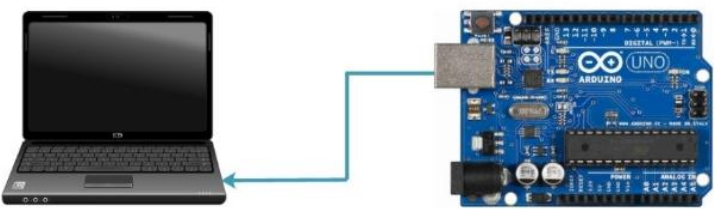

Gambar 15 Proses Pengiriman Data.

Proses pengiriman data dari arduino pada webserver yang terdapat pada laptop adalah sebagai berikut:

1) Serial usb dari arduino dihubungkan pada port usb yang terdapat pada laptop

2) Serial usb dari arduino dihubungkan pada port usb yang terdapat pada laptop

3) Serial usb dari arduino uno akan mengirimkan data jumlah arus_kiri (i_kiri), arus_kanan (i_kanan) dan tegangan (v) pada laptop dimana webserver berada yang sudah terinstall Visual Studio 2008

4) Visual Studio 2008 dibantu MySQL_connector untuk melakukan penyimpanan data kedalam database pemutus_arus.sql, setelah data tersimpan pada database maka webserver dapat membaca nilai dari jumlah arus_kiri (i_kiri), arus_kanan (i_kanan) dan tegangan (v)

5) Visual studio 2008 digunakan sebagai jalan untuk arduino dapat mengirimkan jumlah data pemakaian yang terdeteksi pada rangkaian model dan sebegai jalan untuk webserver ketika memerintahkan proses on dan off pada ruangan melalui aplikasi.

2) Proses Pengontrolan, Pembatas, dan Pemutusan Otomatis
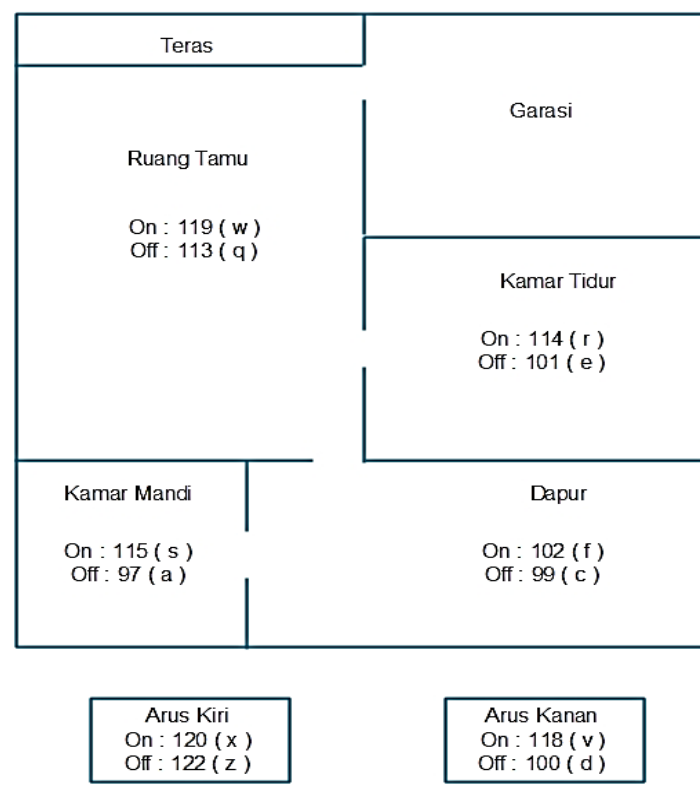

$$
\begin{aligned}
& \text { Arus Kanan } \\
& \text { On : } 118(v)
\end{aligned}
$$$$
\text { Off : } 118(\mathrm{v})
$$

Gambar 16 inisialisasi ruangan.

Proses pengontrolan pada setiap ruangan yang akan dimatikan dan dihidupkan kembali adalah sebagai berikut:

1) Serial usb terhubung pada laptop dimana webserver berada, yang mana laptop tersebut sudah terinstall visual studio 2008, visual studio 2008 berfungsi untuk membantu agar arduino dan webserver dapat saling berkomunikasi.

2) Inisialisasi yang digunakan sebagai perintah untuk proses on dan off arus listrik terdapat pada gambar 4.18 , inisialisai menggunakan kode ASCII yang mana pada kode program arduino meggunakan angka $(119,113,115,97,114$, 101,102, dan 100) untuk ruangan dengan huruf (w,q,s,a,r,e,f, dan d) sedangkan untuk inisialisasi pada proses on dan off di pusat arus kiri menggunakan angka (120,dan 122) huruf (x dan z), pada pusat arus kanan menggunakan angka (118, dan 99) huruf (v dan c). 
3) Ketika pengguna melakukan pengurangan arus di salah satu ruangan, misalkan pada ruang tamu saat tombol on pada halaman ruang ramu di aplikasi berubah menjadi tombol off maka sinyal yang dikirimkan visual studio 2008 kepada interface arduino yaitu angka 113 (q) dengan begitu arduino akan melakukan pemutusan arus listrik pada inisialisai ruang tamu tersebut begitu juga untuk ruangan yang lainnya.

4) Ketika pemutusan otomatis terjadi, ruangan yang akan dimatikan harus didaftarkan terlebih dahulu pada sistem. Ruangan tersebut akan mati ketika pemakaian arus listrik telah melebihi dari nilai batas pemakaian dan tidak ada tindakan pengurangan yang dilakukan oleh pengguna (user).

\section{3) Konfigurasi IP}

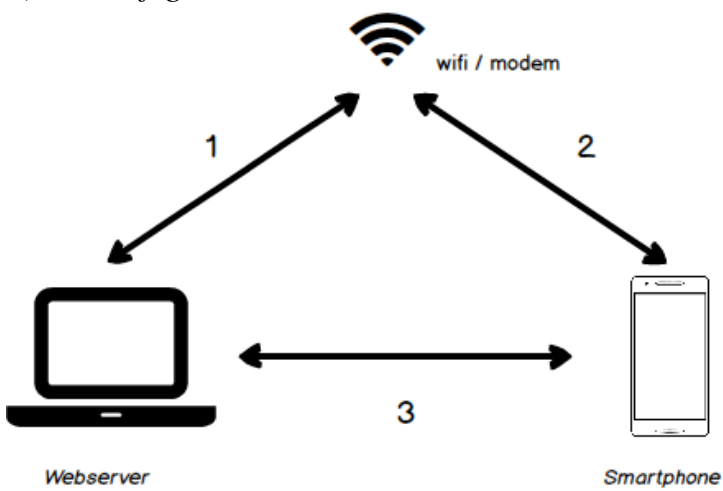

Gambar 17 Koneksi Jaringan.

Pada gambar 17 diatas merupakan skema tentang bagaimana aplikasi pada smartphone dapat diakses dan akan dijelaskan sebagai berikut:

1) Laptop dimana webserver berada dihubungkan dengan modem ataupun wifi.

2) Smartphone dimana aplikasi berada dihubungkan dengan modem ataupun wifi yang sama dengan laptop

3) Setelah laptop dan smartphone berada pada jaringan yang sama maka aplikasi pemutus arus dapat diakses. Hal pertama yang dilakukan yaitu lihat Ip Address pada laptop dimana webserver berada.

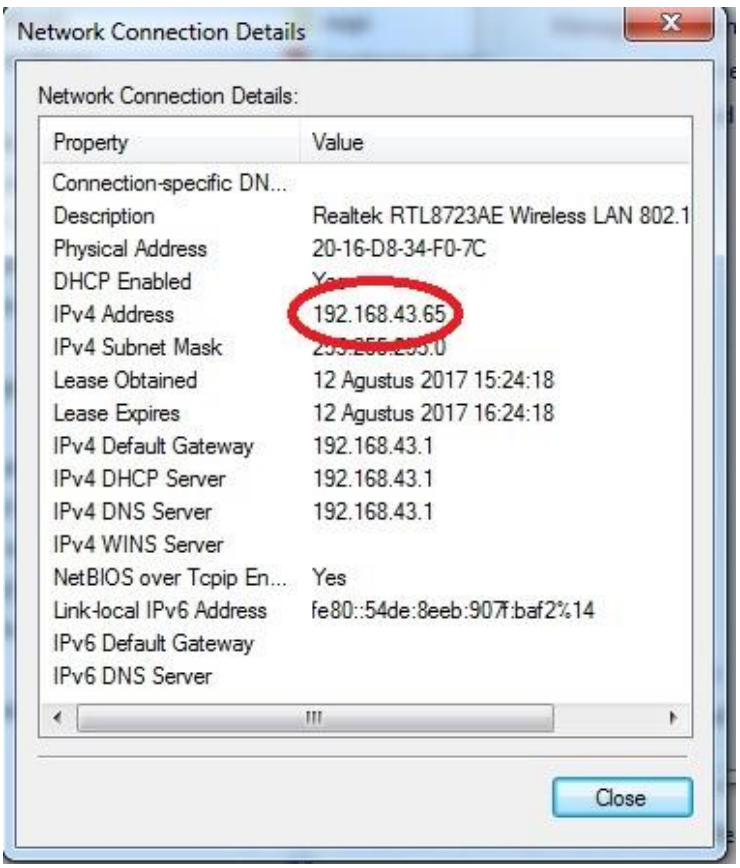

Gambar 18 IP address.

Setelah mengetahui alamat Ip Address dimana webserver berada ketikan Ipv4 192.168.43.65 tersebut pada kolom ip di halaman aplikasi pemutus arus.

\section{KESIMPULAN}

Dari hasil penelitian yang dilakukan dari tahap identifikasi masalah hingga proses pengujian rancang bangun alat pembatas dan pemutus arus listrik pada rumah tangga dan aplikasi pemutus arus, maka dengan adanya aplikasi tersebut dapat disimpulkan bahwa:

1) Prinsip kerja dasar dari sensor arus yaitu dengan prinsip elektromagnetik dimana sensor membaca medan magnet yang ada disekitarnya. Sedangkan dalam penelitian ini sensor arus membaca nilai jumlah arus terpakai pada rangkaian model dengan cara menghubungkan stop kontak pada rangkaian modell dengan sebuah lampu atupun perangkat elektronik kemudian jumlah arus terpakai akan dideteksi oleh sensor.

2) Informasi pemakaian arus listrik yng terpakai ditampilkan pada LCD dan dikirimkan pada aplikasi pengguna dengan menghubungkan arduino pada laptop dimana webserver berada dengan serial usb, data akan disimpan kedalam database pemutus arus kemudian dapat ditampilakn pada aplikasi pemutus arus pada smarthphone pengguna. 
3) Proses on dan off pada aplikasi dapat dilakukan dengan menginisialisasikan setiap relay yang terhubung pada stop kontak dirangkaian model dengan menggunakan kode ascii pada kode program arduino.

4) Pemberitahuan akan dikirimkan pada aplikasi apabila pemakaian arus listrik telah melebihi nilai batas pemakaian arus listrik yang diatur pada sistem, begitu juga dengan bunyi buzzer.

5) Pemutusan otomatis pada sistem dilakukan dengan mendaftarkan terlebih dahulu ruang mana yang akan dimatikan arusnya ketika pemakaian arus listrik telah melebihi nilai batas pemakaian dan tidak ada tindakan pengurangan pemakaian oleh pengguna (user).

6) Aplikasi dappat diakses oleh pengguna ketika smartphone dan webserver berada pada jaringan yang sama.

7) Dengan adanya sistem pengontrol, pembatas dan pemutus arus ini maka diharapkan dapat membantu pengguna dalam mengontrol dan membatasi pemakaian energi listrik, serta penghematan energi listrik dapat dilaksanakan.

\section{DAFTAR PUSTAKA}

[1] (t.thn.). Dipetik Juli 27, 2017, dari library.binus.ac.id:

http://library.binus.ac.id/eColls/eThesisdo c/Bab2/2012-1-01410-

IF\%20Bab2001.pdf

[2] Ardi, B. K., \& Subchan. (t.thn.). Peranan Perkembangan Aplikasi Smartphone Terhadap Pelayanan Perbangkan di Indonesia. Diambil kembali dari ejurnal.stiedhar maputra-smg.ac.id/index.php/

JEMA/article/download/208/178

[3] Fitriandi, A., Komalasari, E., \& Gusmedi, H. (Volume 10, No. 2 Mei 2016). Rancang Bangun Alat Monitoring Arus dan Tegangan Berbasis Mikrokontroler Dengan SMS Gateway. ELECTRICIANJurnal Rekayasa dan Teknologi Elektro.

[4] Hani, S. (2009, Desember). Proteksi Arus Lebih dengan Menggunakan Sensor ACS 706ELC. Jurnal Teknologi Jurusan Teknik Elektro, Fakultas Teknologi Industri Institusi Sains \& Teknologi AKPRIND Yogyakarta, 167-175.
[5] Harianto, Fransiscus, \& Rasmana, S. T. (2016). Rancang Bangun Alat Pembatas Arus Listrk dan Monitoring Pemakaian Daya Pada Rumah Sewa Berbasis Mikrokontroler Arduino Uno. Journal Of Control and Network System (JCONES Vol.5 No.1 Stikom Surabaya).

[6] Hoffer, J. A. (1996). State Transition Diagram. Dipetik Juli 25, 2017, dari http://1304309.blog.upi.edu/2015/03/01/st ate-transition-diagram-2/

[7] Kho, D. (t.thn.). Pengertiaan MCB (Miniature Circuit Breaker) dan Prinsip kerja. Dipetik Juli 26, 2017, dari teknikelektronika.com: http://teknikelektronika.com/pengertianmcb-miniature-circuit-breaker-prinsipkerja-mcb/

[8] Lengkong, Hendra Nugraha; ST.,MT, Alicia A.E. Sinsuw; ST.,MT, Arie S.M Lumenta;. (2015). Perancangan Penunjuk Rute Pada Kendaraan Pribadi Menggunakan Aplikasi Mobile GIS Berbasis Android yang Terintegrasi pada Google Maps. E-Journal Teknik Elektro dan Komputer.

[9] LIPI, T. (2004, Desember 22). Artikelartikel populer. Dipetik April 10, 2017, dariwww.energi.lipi.go.id:

http://www.energi.lipi.go.id/utama.cgi?art ikel\&1101089425\&9

[10] Nasruddin, Ariantara, B., Kusuma, H., Amin, M., Winata, A., Novianto, S., Anggora, T. (2016). CLEAN ENERGY. Kapita Selekta Teknik Mesin 2016. Dipetik April 2017, 11

[11] Perdana, S. P., Syahrial, \& Saodah, S. (2014, Januari). Rancang Bangun Model Pembatas Arus Listrik Berbasis Mikrokontroler ATmega328 dengan Modul Arduino Uno. Jurnal Reka Elektronika, 2 No.1.

[12] Prasetiyo, A. F. (t.thn.). App Inventor Untuk Pemula. Surya University, 1-91.

[13] Rangkuti, S. (2016). Arduino dan Proteus. Bandung: Informatika Bandung.

[14] Sakti, S. P. (Januari-Juni 2016). Rancang bangun Sistem Pembatas Arus daya Kecil Tegangan 220VAC Berbasis Mikrokontroller. Teknologi Elektro Vol.5 No.1. 
[15] Sulistyowati, R., \& Febriantoro, D. D. (mei 2012). Perancangan Prototype Sistem Kontrol dan Monitoring Pembatas Daya Listrik Berbasis Mikrokontroler. Jurnal IPTEK vol.16 No.1.

[16] Supriyanto, E., Setyantoko, A. W., \& Silaturokhim, M. Z. (2016, Oktober). Rancang Bangun Alat Pendeteksi Dini untuk Drop Tegangan Berbasis SMS Gateway. JURNAL TELE, 13 No.2.

[17] Suryaningsih, S., Hidayat, S., \& Abid, F. (2016, Oktober). Rancang Bangun Alat Pemantau Penggunaan Energi Listrik Rumah Tangga Berbasis Internet. Prosi- ding Seminar Nasional Fisika (E-Journal), V.

[18] Taufik, M. (2011, Juli). Rancang Bangun Rangkaian Pembatas Arus Untuk Sistem Sel Surya Dengan Opsi Dual Output Voltage Baterai. SKRIPSI, Fakultas Teknik Departement Teknik Elektro Universitas Indonesia .

[19] Werdaya, N. M. (2012). Pengembangan Media Pembelajaran Berbasis Video untuk Meningkatkan Kemampuan Pemahaman Peserta Didik Pada Standar Kompetensi Memelihara Transmisi Di SMK Negeri 8 Bandung. repository.upi.edu, 37. 